\title{
Assessment of sampling and DNA extraction methods for identification of grapevine trunk microorganisms using metabarcoding
}

\author{
Dion C. Mundy ${ }^{1, *}$, Bhanupratap R. Vanga ${ }^{2}$, Sarah Thompson ${ }^{2}$ and Simon Bulman ${ }^{2,3}$ \\ ${ }^{1}$ The New Zealand Institute for Plant \& Food Research Limited, Marlborough Wine Research \\ Centre, PO Box 845, Blenheim, New Zealand \\ ${ }^{2}$ The New Zealand Institute for Plant \& Food Research Limited, Private Bag 4704, Christchurch \\ 8140, New Zealand \\ ${ }^{3}$ Better Border Biosecurity (B3), New Zealand (www.b3nz.org) \\ ${ }^{*}$ Corresponding author: dion.mundy@plantandfood.co.nz
}

\begin{abstract}
For a deeper understanding of grapevine trunk disease (GTD) in New Zealand, a cheap, rapid, sensitive method for identifying within-vine microbial communities is required. Wood tissue from grapevine trunks was collected and three different DNA extraction methods were compared: a cetyltrimethylammonium bromide (CTAB) method; the Geneaid Plant Genomic DNA Mini Kit; and the Qiagen DNeasy Plant Mini Kit. DNA samples from the CTAB and Geneaid methods were used for MiSeq DNA metabarcoding targeting the ribosomal internal transcribed spacer 1 (ITS1) region. DNA produced by the CTAB method was of a greater quantity and quality than for the other two methods, although the majority of the DNA samples provided polymerase chain reaction (PCR) amplification of fungal DNA sequences. Fungal metabarcoding profiles from the CTAB and Geneaid samples indicated the presence of fungi normally associated with GTD in New Zealand. The CTAB method was chosen for subsequent work due to its low-cost, simplicity and effective detection of typical GTD fungi. The complete process of sampling through to metabarcoding is now used annually as part of a wider ecological study, screening more than 600 vines at 12 Marlborough vineyards.
\end{abstract}

Keywords DNA extraction, next generation sequencing, grapevine trunk microorganisms, PCR, metabarcoding.

\section{INTRODUCTION}

Grapevine trunk disease (GTD) diminishes vineyard longevity and productivity in all winegrape production regions of the world, causing significant economic losses. The impact of GTD usually becomes more severe as the vineyard ages, which threatens the sustainability of the $\$ 2.60$ billion New Zealand wine industry (Sosnowski \& Mundy 2016). In many wine regions of Australia, up to $100 \%$ of the vines in older vineyards are diseased and yield losses of $1500 \mathrm{~kg} /$ ha have been reported (Wicks \& Davies 1999). In California, the cost of trunk disease to the industry has been estimated at US $\$ 260$ million per annum (Siebert 2001). In New Zealand, trunk disease threatens the entire national crop $(36,192$ ha; HortNZ 2016). Over the past few decades, the incidence of the GTDs eutypa dieback (caused by Eutypa lata) and botryosphaeria dieback (caused by Botryosphaeriales) has increased considerably worldwide, including in the wine regions of New Zealand (Mundy et al. 2009a; Bertsch et al. 2013). In a survey of 41 vineyards across the North and South Islands, eutypa and botryosphaeria dieback-causing fungal species were cultured 
from $68 \%$ and $54 \%$ of vineyards, respectively (Mundy et al. 2009a).

Detection of fungi by culturing is slow and problematic. Eutypa lata and Botryosphaeriaceae species often over-grow plates within a week, masking the presence of other slower-growing fungi, such as Phaeomoniella chamydospora (associated with young vine decline and the esca complex). Despite good overall knowledge of the symptomologies of the fungi associated with eutypa and botryosphaeria dieback, the mechanisms underlying disease development, and the impact of difficult-to-culture, unidentified pathogenic trunk fungi, is largely unknown. The importance of multiple-pathogen infections is also poorly understood (Jones 2001). DNA sequence data is a key source of information for diagnostic and classification of plant pathogenic fungi. Recent advancements in genome sequencing technologies allow rapid cataloguing of the entire repertoire of plant pathogens, including data for previously uncharacterised organisms (Agler et al. 2016).

The objective of this study was to develop an efficient and robust method to detect multiple fungal pathogens within grapevine trunks. This required the extraction and purification of fungal DNA from samples of internal woody tissue. Isolating DNA free from inhibitors is essential for amplification by polymerase chain reaction (PCR), but this is challenging in grapevine trunks, which contain large quantities of secondary metabolites such as polyphenols, tannins, polysaccharides and resinous materials. DNA metabarcoding is a sensitive technique for detecting multiple organisms in a sample, but it is susceptible to DNA and microorganism contamination. For accurate studies of GTDs, it is important to gather field samples in a timely manner, to limit problems with DNA degradation or growth of contaminating microbial populations during transport. For these reasons, we needed to design a rapid method for sampling vines in the field.

In this study, we compared three techniques for DNA preparation coupled with snap freezing of cored trunk tissue in the field. DNA from two
DNA extraction methods was examined by DNA metabarcoding targeting the fungal ribosomal internal transcribed spacer 1 (ITS1) gene region.

\section{MATERIALS AND METHODS \\ Tissue sampling}

To collect tissue samples from the trunks of Sauvignon blanc vines, bark was removed with a sterile knife and the inner wood drilled to approximately $40 \mathrm{~mm}$ with a $4-\mathrm{mm}$ drill bit sterilised in 3\% (v/v) hypochlorite solution. The drilled hole was sealed with linseed wood putty $\left(\right.$ Selleys $\left.{ }^{\oplus}\right)$ to prevent subsequent infection of the wound. To avoid overheating and cross contamination, a new drill bit was used for each trunk. Drilled tissue samples were placed in 4-mL sterile cryogenic tubes (Thermo Scientific) and snap frozen in liquid nitrogen. The sample tubes were stored in the laboratory at $-80^{\circ} \mathrm{C}$.

Core samples were collected from Brancott Estate vineyard block (Marlborough) which has a high level of trunk disease based on past visual disease identification and culture-based sampling (Mundy \& McLachlan 2016). For the initial exploratory experiments, 2-3 cores were drilled from each of five plants. The resulting tissue material from the five plants was combined and mixed prior to subsampling for extraction. For the second round of DNA extractions, trunk cores were collected from 41 individual plants. Each DNA extraction was then completed on cores collected from an individual plant.

Two replicates of grape leaf DNA extractions were completed from $1 \mathrm{~cm}^{2}$ tissue discs with the CTAB and Geneaid methods.

\section{Exploratory DNA extraction}

Genomic DNA was isolated using one of three methods: (i) cetyltrimethylammonium-bromide (CTAB)-based procedure (Murray \& Thompson 1980) with modifications; (ii) Geneaid Plant Genomic DNA Mini Kit; or (iii) Qiagen DNeasy Plant Mini Kit.

CTAB procedure: Briefly, 50 or $100 \mathrm{mg}$ of wood tissue was homogenised using a Mini-BeadBeater 8 (BioSpec Products) in $800 \mu \mathrm{L}$ of CTAB 
extraction buffer (100 mM Tris hydrochloride (Tris- $\mathrm{HCl}) \mathrm{pH} 8.0,1.4 \mathrm{M}$ Sodium chloride $(\mathrm{NaCl})$, $20 \mathrm{mM}$ ethylenediaminetetraacetic acid (EDTA), $2 \%$ CTAB, $4 \%$ polyvinylpyrrolidone, $0.4 \%$ $\beta$-mercaptoethanol) containing $1 \mathrm{~g}$ of $2.3-\mathrm{mm}$ steel beads for $90 \mathrm{~s}$. The samples were incubated at $65^{\circ} \mathrm{C}$ for $90 \mathrm{~min}$ or overnight, extracted with an equal volume of chloroform:isoamyl alcohol (24:1) and centrifuged at $15,600 \mathrm{x} g$ for $10 \mathrm{~min}$. The DNA solution was precipitated with 0.54 volume of isopropanol and 0.08 volume of 7.5 $\mathrm{M}$ chilled ammonium acetate and incubated overnight at $-20^{\circ} \mathrm{C}$. After centrifugation $(15,600$ $\mathrm{x} \mathrm{g}$ for $30 \mathrm{~s}$ ), the supernatant was discarded, the DNA pellet rinsed with $70 \%$ ethanol and air dried for $15 \mathrm{~min}$. The DNA pellet was resuspended in $40 \mu \mathrm{L}$ of sterile molecular grade $\mathrm{H}_{2} \mathrm{O}$ (Thermo Scientific) and incubated at $37^{\circ} \mathrm{C}$ for $30 \mathrm{~min}$ to completely resuspend the DNA.

Geneaid Plant Genomic DNA Mini Kit or the Qiagen DNeasy Plant Mini Kit: For the two approaches involving commercial kits, wood and leaf tissue was homogenised, as above, in $800 \mu \mathrm{L}$ of AP1 buffer (Qiagen) or GPX1 buffer (Geneaid). Samples were then incubated at $65^{\circ} \mathrm{C}$ for $90 \mathrm{~min}$ and DNA was subsequently isolated according to the manufacturer's instructions. Extraction controls were completed as for other DNA extraction procedures, but $1 \% \mathrm{NaCl}$ saline solution was substituted for grapevine tissue. All DNA extracts were quantified using NanoDrop ND-1000 spectrophotometer (NanoDrop Technologies, Wilmington, DE, USA).

\section{PCR for fungal DNA amplification}

The primers NSIla

(5'-GATTGAATGGCTTAGTGAGK-3') and 58A2R (5'-AGTCCTGCGTTCTTCATCGAT-3') were used to amplify the ITS1 region of the fungal ribosomal RNA (rRNA) gene (Martin \& Rygiewicz 2005). PCRs were performed in a total volume of $20 \mu \mathrm{L}$ containing $1 \mu \mathrm{L}$ of template DNA, $0.2 \mathrm{U}$ of KAPA3G plant DNA polymerase (Kapa Biosystems), $10 \mu \mathrm{L}$ of PCR master mix (KAPA3G plant PCR kit) and $0.5 \mu \mathrm{L}$ of $10 \mu \mathrm{M}$ of each primer. PCRs were carried out in a T100 thermal cycler (Bio-Rad) with the following steps: denaturation at $94^{\circ} \mathrm{C}$ for $4 \mathrm{~min}$, amplification for 35 cycles at $94^{\circ} \mathrm{C}$ for $20 \mathrm{~s}$, annealing at $50^{\circ} \mathrm{C}$ for $20 \mathrm{~s}$, elongation at $72^{\circ} \mathrm{C}$ for $60 \mathrm{~s}$ and a final extension phase at $72^{\circ} \mathrm{C}$ for $7 \mathrm{~min}$. All PCRs included a negative, no template control.

\section{Quantitative PCR (qPCR)}

qPCR was performed using a StepOnePlus ${ }^{\mathrm{m}}$ Real-Time PCR system (Applied Biosystems). To test for the presence of PCR inhibitors, separate qPCR reactions were carried out on $1 \mu \mathrm{L}$ of the extracted DNA ( $40 \mathrm{ng})$ mixed with $1 \mu \mathrm{L}$ of a $10: 3$ dilution $(0.1 \mathrm{ng} / \mu \mathrm{L})$ of a synthetic biomarker 'B3' plasmid (A. Pitman et al. unpublished), $1 \times$ SYBR Green qPCR master mix (BioRad), $300 \mathrm{nM}$ of each primer (B3_F/B3_R) (A. Pitman et al. unpublished) in a total volume of $20 \mu \mathrm{L}$. Two control reactions contained the plasmid alone. To assess the level of inhibition, the cycle thresholds (Cts) of the reactions containing extracted DNA were compared to the Cts of these control samples. The PCR conditions were: $5 \mathrm{~min}$ at $95^{\circ} \mathrm{C}$, then $40 \mathrm{cycles}$ of $15 \mathrm{~s}$ at $95^{\circ} \mathrm{C}, 20 \mathrm{~s}$ at $60^{\circ} \mathrm{C}$ and $20 \mathrm{~s}$ at $72^{\circ} \mathrm{C}$. Samples were run in duplicate. Melt curve analyses were performed after each qPCR to assess the specificity of amplification.

\section{DNA metabarcoding}

Illumina MiSeq sequencing was performed on nine arbitrarily chosen samples from each of the CTAB (1A, 3A, 5A, 6A, 8A, 9A, 10A, 11A, 12A) and the Geneaid $(1 \mathrm{~B}, 3 \mathrm{~B}, 5 \mathrm{~B}, 6 \mathrm{~B}, 8 \mathrm{~B}, 9 \mathrm{~B}, 10 \mathrm{~B}$, $11 \mathrm{~B}, 12 \mathrm{~B}) \mathrm{DNA}$ extractions from the wood tissue collected at Brancott Estate. PCR products were prepared as per the Illumina 16S Metagenomic Sequencing Library Preparation guide (https:// support.illumina.com/). PCRs were performed in duplicate. PCR products were purified using AMPure XP PCR purification system (Agencourt) and quantified using a NanoDrop ND-1000 spectrophotometer. Concentrations were adjusted to $10 \mathrm{ng} / \mu \mathrm{L}$ for sequencing. Purified PCR amplicons were indexed and pairend ( $300 \mathrm{bp}$ PE) sequenced by the New Zealand Genomics Limited (Auckland). 


\section{Analysis of Next-Generation DNA Sequencing data}

The sequence reads were quality filtered, paired ends were overlapped, and sequences clustered into Operational Taxonomic Units (OTUs) using a customised pipeline: USEARCH and python barcode script (http://drive5.com/usearch/). R-markdown was utilised to record the analysis coding. The OTUs with total sequence reads below 50 were discarded from the analysis. The OTU exemplar sequences were identified using BlastN against the GenBank non-redundant database (NCBI, Bethesda, MD, USA or the UNITE fungal reference database (https://unite. ut.ee).

\section{RESULTS \\ DNA isolation}

In an initial exploratory experiment, DNA was isolated using the CTAB method, Genaid or Qiagen kits. For each extraction method, a narrow range of variations of tissue weight, homogenisation order, or incubation times were included (Table 1). While individual protocol variations were not replicated, the six extracts from CTAB methods had higher concentrations than those from either the Geneaid or Qiagen DNA extraction kits (Table 1). Based on these exploratory experiments, a CTAB extraction involving $100 \mathrm{mg}$ tissue homogenised in CTAB buffer for $90 \mathrm{~min}$ at $65^{\circ} \mathrm{C}$ was used in subsequent experiments.

After this initial exploration, DNA was extracted from 41 grapevine trunks. DNA isolated using the CTAB method was of substantially higher average concentration than from the Geneaid kit (Table 2). In gel electrophoresis of a selection of DNA samples (Table 2), the CTAB method produced visible bands of high molecular weight DNA as well as RNA (Fig. 1) whereas DNA from the Geneaid kit was difficult or impossible to detect. By comparison, extractions of grapevine leaf tissue produced large amounts of DNA from both the CTAB and Genaid protocols (Table 2).

Table 1 Exploratory DNA extraction experiment. Extraction in cetyltrimethylammonium bromide (CTAB) solution, or with the Qiagen DNeasy Plant Mini Kit or the Geneaid Plant Genomic DNA Mini Kit. DNA concentrations were measured using a NanoDrop.

Method DNA concentration $(\mathrm{ng} / \mu \mathrm{L})$

$50 \mathrm{mg}$ tissue, homogenised in $\mathrm{CTAB}, 90 \mathrm{~min}$ at $65^{\circ} \mathrm{C}$

$100 \mathrm{mg}$ tissue, homogenised in $\mathrm{CTAB}, 90 \mathrm{~min}$ at $65^{\circ} \mathrm{C}$

$50 \mathrm{mg}$ tissue, homogenised before $\mathrm{CTAB}, 90 \mathrm{~min}$ at $65^{\circ} \mathrm{C}$

$100 \mathrm{mg}$ tissue, homogenised before CTAB, $90 \mathrm{~min}$ at $65^{\circ} \mathrm{C}$

$50 \mathrm{mg}$ tissue, homogenised in $\mathrm{CTAB}$, overnight at $65^{\circ} \mathrm{C}$

$100 \mathrm{mg}$ tissue, homogenised in $\mathrm{CTAB}$, overnight at $65^{\circ} \mathrm{C}$

$50 \mathrm{mg}$ tissue, homogenised in AP1 buffer (Qiagen Kit)

$100 \mathrm{mg}$ tissue, homogenised in AP1 buffer (Qiagen Kit)

50 mg tissue, homogenised in GPX1 buffer (Geneaid Kit) 
Table 2 Summary of the concentrations $(\mathrm{ng} / \mu \mathrm{L})$ of grapevine trunk genomic DNA isolated using the cetyltrimethylammonium bromide (CTAB) and Geneaid Plant Genomic DNA Mini Kit extraction methods. Extraction controls from a saline solution and comparative extractions from grapevine leaf tissue discs are also shown. DNA concentrations were measured using a NanoDrop. The average concentration of 41 trunk DNA samples for each method is shown.

\begin{tabular}{lcc}
\hline Concentration $(\mathrm{ng} / \mu \mathrm{L})$ & CTAB & Geneaid \\
\hline Average trunk $(\mathrm{n}=41)$ & 145.4 & 15.5 \\
No. samples less than $10 \mathrm{ng} / \mu \mathrm{L}$ & 2 & 16 \\
Range & $4.3-426.4$ & $2.0-44.7$ \\
Saline control & 1.7 & 0.4 \\
Average leaves $(\mathrm{n}=2)$ & 305.8 & 457.6 \\
\hline
\end{tabular}

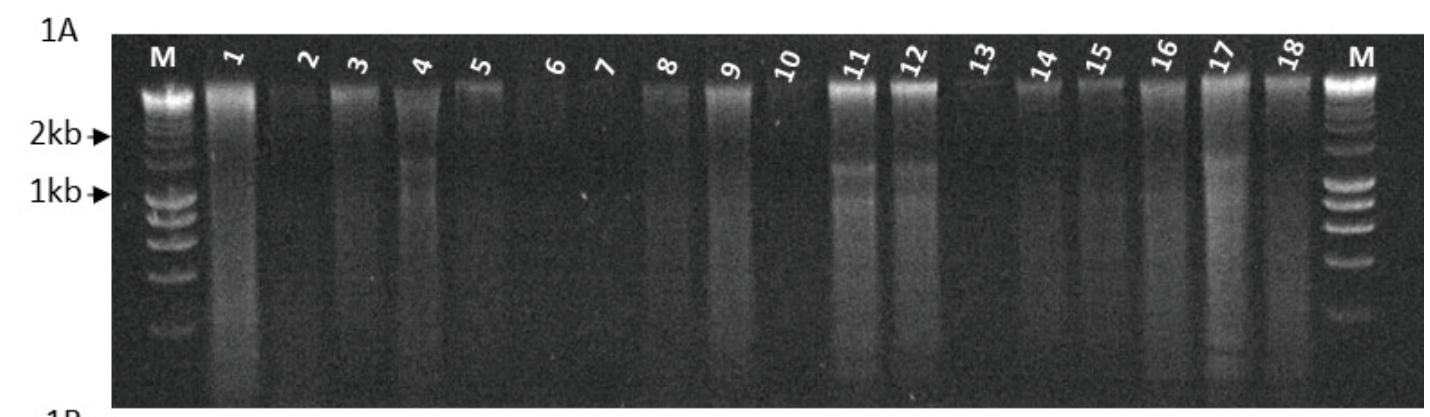

$1 \mathrm{~B}$

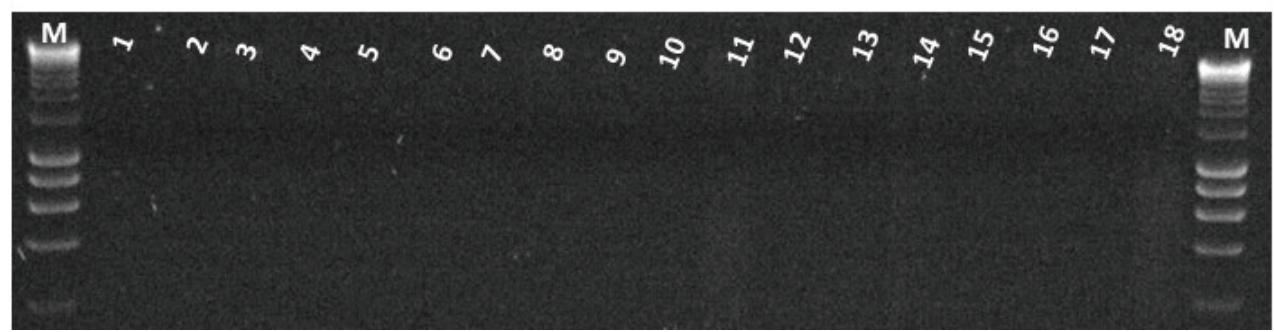

Figure 1 Gel electrophoresis of grapevine trunk nucleic acids isolated using 1A) cetyltrimethylammonium bromide (CTAB) extraction, and 1B) Geneaid Plant Genomic DNA Mini Kit. Lane $\mathrm{M}=$ HyperLadder $1 \mathrm{~kb}$ (size range from $10037 \mathrm{bp}$ to $200 \mathrm{bp}$ ). Note presence of total RNA below $2 \mathrm{~kb}$ in the majority of CTAB preparations (1A).

\section{PCR amplification}

Fungal ITS1 amplicons were amplified from the bulk of the CTAB extracted DNA and, despite their low yields, also from the Geneaid extracts (Fig. 2). No amplicons were detected from the negative saline extraction controls (7A and 7B). The CTAB method produced no amplicon from two (6A and $34 \mathrm{~A}$ ) of 41 trunk core samples whereas the Geneaid DNA Mini Kit yielded no amplicons for five (2B, 22B, 28B, 31B, and 33B) of 41 trunk samples.

\section{qPCR testing to identify the presence of inhibitors in the DNA}

qPCR was performed to test whether inhibitors were present in the genomic DNA. Amplifications of the B3 plasmid alone gave an average $\mathrm{Ct}$ of 20.20. Amplifications in the presence of 


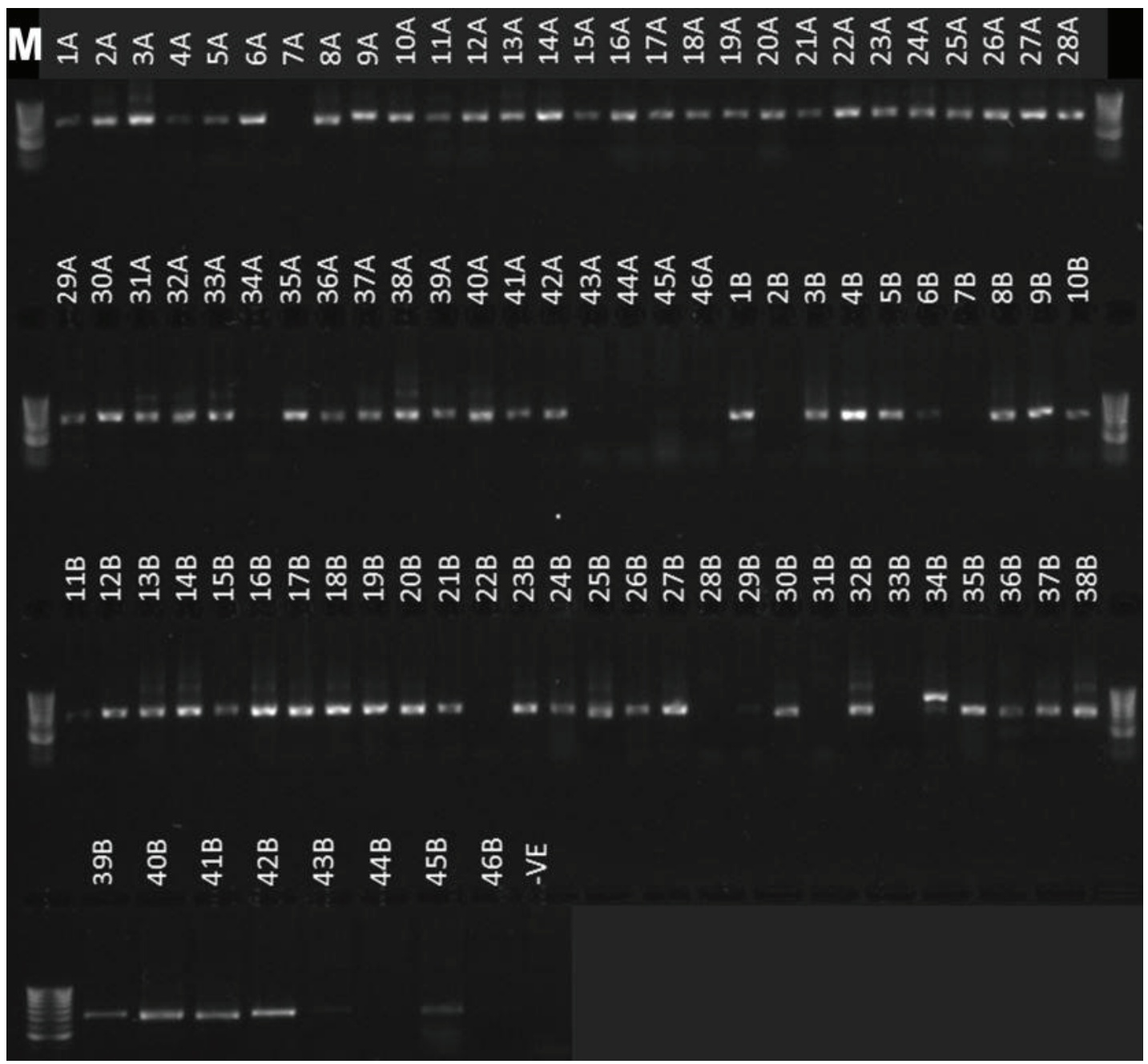

Figure 2 Polymerase Chain Reaction (PCR) amplification of the fungal internal transcribed spacer 1 (ITS1) region from grapevine trunk DNA paired samples 1 to 46 . 1A to 46A: PCR amplification from cetyltrimethylammonium bromide (CTAB) extracted DNA extraction method. 1B to $46 \mathrm{~B}$ : PCR amplification of the ITS1 region from Geneaid Plant Genomic DNA Mini Kit extracted DNA. Expected size of the PCR amplicon: $\sim 550 \mathrm{bp}$. Lane $\mathrm{M}=$ HyperLadder1kb. $-\mathrm{VE}=$ negative no template PCR.

grapevine DNA extracts yielded very similar Ct values (ranged between 20.19 to 20.99), indicating that the DNA samples had minimal inhibitors. Melt curve analyses indicated that correct B3 amplicons were amplified from both sample sets (not shown).

\section{DNA metabarcoding}

To explore whether there was bias of fungal genus between the extraction methods, DNA metabarcoding was performed for nine DNA samples each from the CTAB and Geneaid methods. Both extraction methods gave comparable metabarcoding profiles, including fungi normally associated with GTD in New 
Zealand such as Phaeomoniella chlamydospora, Eutypa lata and Neofusicoccum sp. (Fig. 3). No attempt was made to differentiate closely related taxa such as Neofusicoccum, Diplodia, Dothidea, Lasidiplodia and Botryosphaeria, collectively referred to as Botryosphaeriales in this study; we focused on extraction bias not vineyard ecology. While the profiles of the two extraction methods did vary slightly, the key differences were driven by OTUs found in single extractions. For instance, Ilyonectria was found predominantly in a single CTAB extraction and Phomopsis/Diaporthe was found in a single Geneaid extraction, suggesting sample-to-sample variation rather than extraction bias. A total of 163 fungal OTUs were detected in the DNA samples extracted by both methods.

\section{DISCUSSION}

The internal portion of woody plants is difficult to access and wood material is challenging for DNA extraction. For repeated analyses of trunk microbial communities, efficient processes to minimise plant harm are required. Previous trunk sampling for microbial isolation used a 10 -mm core across the full diameter of the trunk (Mundy et al. 2009a), or destructive sampling of the vine (Mundy et al. 2009b). Here, we developed a refinement of the sampling and extraction process, recovering trunk material suitable for consistent preparation of DNA. The new process involved drilling of smaller cores, snap freezing in the field, and a simple, cheap, DNA extraction protocol. Vines have shown no obvious signs of ill health following three years of sampling (D. Mundy, unpublished observations).

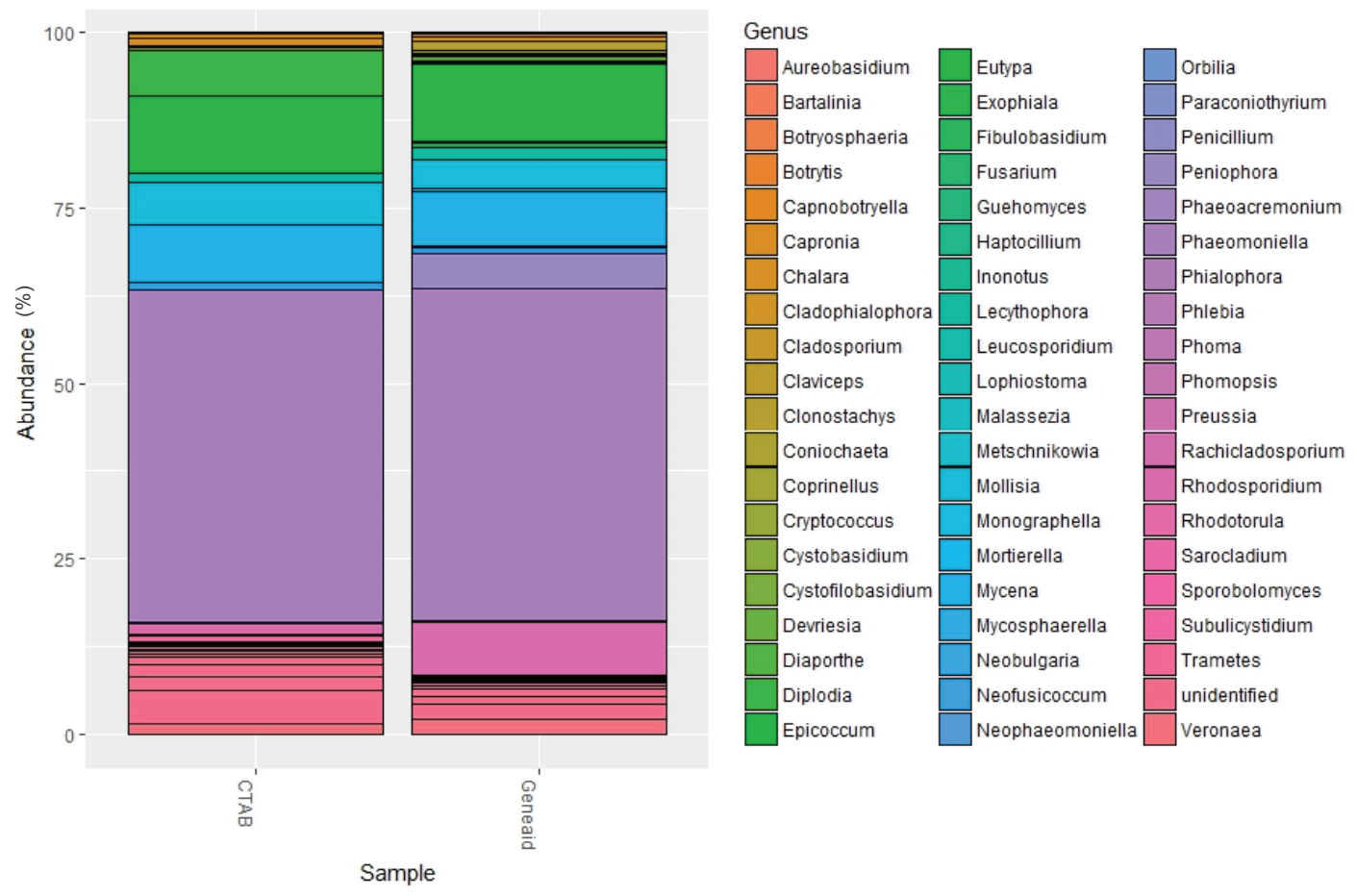

Figure 3 Operational Taxonomic Units (OTUs), identified at genus level, for the CTAB and Geneaid extraction techniques. OTUs are summed by extraction method (nine samples for each method) and normalised by library size. 
Specific identification of fungi was not the primary target outcome of this set of experiments. Nevertheless, we did observe that the DNA metabarcoding from trunk DNA detected a range of fungi (Fig. 3) consistent with past New Zealand vineyard surveys (Jones 2001; Mundy et al. 2009a), and with international studies of grapevine trunk diseases (Bertsch et al. 2013; Lawrence et al. 2017; MoralesCruz et al. 2018). These observations further supported the suitability of the CTAB method for detecting GTD associated microorganisms. The sequence analysis process used for the DNA metabarcoding provided identification to genus level and increased resolution will be provided by new analysis techniques in combination with isolate collections from New Zealand grapevines.

Aside from the total yield of extracted DNA, a remaining question was whether the CTAB method works well with some fungi but not others. We compared the representations of fungi detected from the CTAB and Geneaid genomic DNAs; the (combined) most abundant OTU numbers were similar from the CTAB and Geneaid extraction methods. The main differences between the extraction methods were found in single extractions. CTAB extraction protocols have been used for many years and have been successfully applied to a wide range of difficult-to-extract fungi and plant tissues (Lodhi et al. 1994; Porebski et al. 1997; Cheng et al.1997; Hill et al. 2014); we expected that a CTAB method should be successful for the broad suite of fungi found in grapevines. This method was chosen for subsequent work due to its low-cost, simplicity, and effective detection of many typical grapevine trunk fungi.

We observed significant variations in DNA yield between trunk samples. In a few cases, we also observed variation between the metabarcoding results derived from subsamples of a trunk core (albeit with different extraction techniques). These results confirm that sample replication remains important in our future metabarcoding studies.

Our overall process for sampling and preparing DNA is now being used as a research tool for the annual screening of more than 600 vines at 12 Marlborough vineyards as part of a wider ecological study.

\section{ACKNOWLEDGEMENTS}

This work was funded by New Zealand Winegrowers Inc., as part of the Vineyard Ecosystems programme (PFR 32476, NZW 14102). The authors would like to thank Hayley Ridgway and Karmun Chooi of The New Zealand Institute for Plant and Food Research Limited for reviewing the draft manuscript. We would also like to thank Pernod Ricard Winemakers for providing plant tissue for sampling during the development of this project.

\section{REFERENCES}

Agler MT, Ruhe J, Kroll S, Morhenn C, Kim S-T, Weigel D, Kemen EM 2016. Microbial hub taxa link host and abiotic factors to plant microbiome variation. PLoS Biol 14: e1002352.

Bertsch C, Ramírez-Suero M, Magnin-Robert M, Larignon P, Chong J, Abou-Mansour E, Spagnolo A, Clément C, Fontaine F 2013. Grapevine trunk diseases: complex and still poorly understood. Plant Pathology 62: 243265.

Cheng FS, Brown SK, Weeden NF 1997. A DNA extraction protocol from various tissues in woody species. HortScience 32: 921-922.

Hill GN, Evans KJ, Beresford RM, Dambergs RG 2014. Comparison of methods for the quantification of botrytis bunch rot in white wine grapes. Australian Journal of Grape and Wine Research 20: 432-441

HortNZ 2016. Grape and wine production 2011 \& 2016. In: Aitken AG, Hewett EW eds. Freshfacts 2016. New Zealand Institute for Plant \& Food Research, Auckland, New Zealand. P. 8.

Jones PE 2001. The development of diagnostic tools for the grapevine pathogen Eutypa lata. Unpublished MSc thesis, Massey University, Palmerston North, New Zealand. 136 p.

Lawrence DP, Travadon R, Nita M, Baumgartner K 2017. TrunkDiseaseID.org: A molecular 
database for fast and accurate identification of fungi commonly isolated from grapevine wood. Crop Protection 102: 110-117.

Lodhi MA, Ye GN, Weeden NF, Reisch BI 1994. A simple and efficient method for DNA extraction from grapevine cultivars and Vitis species. Plant Molecular Biology Reporter 12: 6-13.

Martin KJ, Rygiewicz PT 2005. Fungal-specific PCR primers developed for analysis of the ITS region of environmental DNA extracts. BMC Microbiology 5: 28-28.

Morales-Cruz A, Allenbeck G, Figueroa-Balderas $\mathrm{R}$, Ashworth VE, Lawrence DP, Travadon $\mathrm{R}$, Smith RJ, Baumgartner K, Rolshausen PE, Cantu D 2018. Closed-reference metatranscriptomics enables in planta profiling of putative virulence activities in the grapevine trunk disease complex. Molecular Plant Pathology: 19: 490-503.

Mundy DC, Casonato SG, Manning MA 2009a. Incidence of fungi isolated from grape trunks in New Zealand vineyards. Guest D ed. APPS Plant Health Management: An Integrated Approach. Australasian Plant Pathology Society. P. 86.

Mundy DC, Casonato SG, Manning MA 2009b. Sampling techniques for isolating trunk disease fungi from a Nelson vineyard. New Zealand Plant Protection 62: 406.

Mundy DC, McLachlan ARG 2016. Visual symptoms of trunk diseases do not predict vine death. New Zealand Plant Protection 69: 17-24.

Murray MG, Thompson WF 1980. Rapid isolation of high molecular weight plant DNA. Nucleic Acids Research 8: 4321-4325.

Porebski LS, Bailey G, Baum BR 1997. Modification of a CTAB DNA extraction protocol for plants containing high polysaccharide and polyphenol components. Plant Molecular Biology Reporter 15: 8-15.

Siebert JB 2001. Eutypa: the economic toll on vineyards. Wines Vines. April: 50-56.

Sosnowski M, Mundy DC 2016. Sustaining vineyards through practical management of grapevine trunk diseases. NZW 13-100.
Adelaide, SA, SARDI. p. 73.

Wicks T, Davies K 1999. The effect of Eutypa on grapevine yield. Australian Grapegrower and Winemaker 426: 15-16. 